\title{
Effect of head positioning on the vertical and horizontal magnification in panoramic radiographs: rotation along the sagittal and transverse plane
}

\author{
Yong-Gun Kim', Jin-Seok Byun², Seo-Young An ${ }^{3 *}$ \\ 'Department of Periodontology, ${ }^{2}$ Department of Oral medicine, ${ }^{3}$ Department of Oral and Maxillofacial Radiology, \\ School of Dentistry, Kyungpook National University, Daegu, Republic of Korea
}

Purpose: The purpose of this study was to investigate the effect of head position changes on vertical and horizontal magnification in dental panoramic radiographs. Materials and Methods: Five $4 \mathrm{~mm}$ metal balls were placed above alveolar crest of dry skull considering extraction socket and dental arch. Panoramic radiographs were taken by OP-100D (Instrumentarium Imaging Co., Tuusula, Finland) at proper and rotated head position along the sagittal and transverse axis at $3-20^{\circ}$ upwardly, downwardly, to the left and to the right rotation. Images were stored in DICOM files and were measured by ruler equipped within INFINITT PACS software. Results: The mean horizontal magnification was $1.22 \pm 0.01-1.44 \pm 0.01$ and mean vertical magnification was $1.29 \pm 0.00$ $-1.35 \pm 0.02$ at standard head position. There was statistical significance of horizontal magnification between the anterior (1.24 \pm 0.02 $-1.31 \pm 0.03)$ and the posterior area $(1.40 \pm 0.03-1.33 \pm 0.02)(P<0.05)$. Vertical magnification resulted in less variation $(1.24 \pm$ $0.01-1.37 \pm 0.02)$ than horizontal magnification $(0.88 \pm 0.03-3.73 \pm 0.16)$ according to the rotation. There was statistical significant difference on horizontal magnification $(P<0.05)$. Conclusion: In rotated head position, the horizontal magnification should be considered because these can cause distortion on panoramic radiographs. (J Dent Rehabil Appl Sci 2014;30(1):1-8)

Key words: head position; magnification; panoramic radiographs

\section{서론}

치과영역에서 임플란트 매식술은 과거에 비해 빠른 속 도로 보편화되고 있고, 다양한 진단검사방법을 통해 임 상에 적용되고 있다. 최근에는 수술의 효율성, 해부학 적 이해, 그리고 최소한의 침습적인 치료를 위해 CBCT (Cone-beam Computed Tomography)나 CT (Computed Tomography)가 사용되고 있다. 이들은 방사선 사진상 의 변형이나 왜곡이 적고, 2 차원적 영상에서 얻을 수 없 는 단면상을 통해 해부학적 구조물을 확인할 수 있어 매 우 유용하나 ${ }^{1}$ 모든 치료에 적용하기는 어렵다. 임상에서 현재 가장 보편적으로 사용하고 있는 영상진단법은 파노

*Correspondence to: Seo-Young An, MS Department of Oral and Maxillofacial Radiology, Kyungpook National University 2177 Dalgubeol-daero, Jung-gu, Daegu, 700-412, Republic of Korea Tel: +82-53-600-7423, Fax: +80-53-425-6025, E-mail: syan@knu.ac.kr Received: December 10, 2013/Last Revision: January 30, 2014/Accepted: March 7, 2014
\end{abstract}

라마방사선사진이다. ${ }^{1-3}$ 파노라마방사선 사진은 촬영시 간이 짧고, 촬영이 간단하며 한 장의 사진으로 악골을 포 함한 넓은 부위를 평가할 수 있고, 상대적으로 방사선 노 출량이 적어 매우 유용하다. ${ }^{4-6}$ 또한 적절한 위치에서 촬 영된 파노라마방사선사진은 잔존 골의 수직 및 수평적인 평가 시에도 비교적 정확한 값을 보인다. ${ }^{7,8}$ 하지만 촬영 시 환자의 위치오류, 파노라마방사선 촬영기기가 자체적 으로 가지고 있는 투사의 원리, 상층의 모양, 수평 및 수 직적 확대 요소간의 차이 등으로 인해 피사체의 크기 및 형태의 측정에 오류가 나타날 수 있어 주의가 필요하다..$^{-11}$ Dhillon $^{12}$ 는 무작위로 고른 1,782명의 파노라마방사선사 진 중 $11 \%$ 만이 환자 위치에 관한 실수나 기술적인 실수
Copyright (C 2014 The Korean Academy of Stomatognathic Function and Occlusion. (c) It is identical to Creative Commons Non-Commercial License. 
가 없이 촬영 되었으며, 환자의 머리 위치에 관한 실수 가 $89 \%$ 였으며, 이중 $24.9 \%$ 는 영상의 질이 부적합하다 고 하였다. 잔조골이 충분한 경우에는 파노라마방사선 사진에 의한 작은 오차가 임플란트 수술과정에서 합병 증을 유발하지 않지만, 잔존골이 부족한 경우에는 1 - 2 $\mathrm{mm}$ 의 오차가 수술실패에 결정적인 원인이 될 수 있다. 즉 환자의 부적절한 머리 위치로 인해 파노라마방사선 사진에서 잔존골의 양이 실제 골 양보다 확대되어 계측 될 경우, 하악의 감각이상, 상악동의 천공 및 임플란트 골유착의 실패 등과 같은 합병증이 나타날 수 있다.

이 연구의 목적은 파노라마방사선사진 촬영기에 건조 두개골을 이상적인 위치와 상방, 하방, 좌측 및 우측으 로 회전시켜 벗어나게 고정 한 후 촬영 위치 에 따른 파노 라마방사선사진의 수평 및 수직 확대율을 평가하는 것이 었다.

\section{연구 재료 및 방법}

악골의 비대칭 및 기형이 없는 건조 두개골의 하악 전 치 두 부위와 우측 대구치 세 부위에 $4 \mathrm{~mm}$ 의 금속구를 유틸리티 왁스로 고정하였다. 좌측에서부터 우측으로 금속구의 위치를 편의상 치아의 위치에 준하여 \#32, 42, $46,47,48$ 로 구분하였다. 모든 금속구의 직경은 Digital caliper T500-181E (Microma ${ }^{\circledR}$, Seoul, Korea) (Fig. 1)로 측정하여 확인하였다. 실험을 위해 고안된 두개골 고정 장치는 수평면을 기준으로 상하로 $30^{\circ}$, 시상면을 기준 으로 좌우로 $20^{\circ}$ 의 회전이 가능하며, 촬영 시 건조 두개 골의 위치 설정을 위해 사용되었다(Fig. 2). 파노라마방 사선사진은 OP-100D (Instrumentarium Imaging Co.,

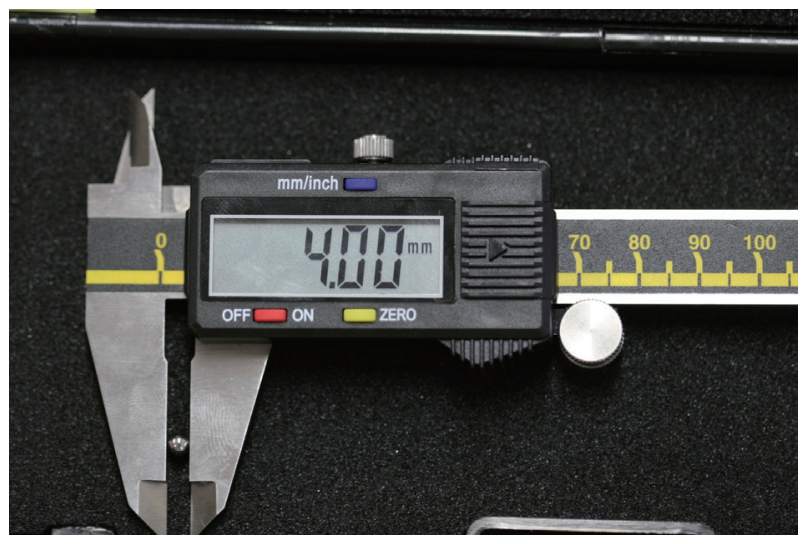

Fig. 1. Measurement of metal ball.
Tuusula, Finland)를 이용하여 관전압 $60 \mathrm{kVp}$, 관전류 2 $\mathrm{mA}$, 노출시간 17.6초로 촬영하였다. 파노라마 장비 교 합제에 상하악 전치의 절단연을 위치시키고, 세 개의 지 시광을 정중 시상면, 프랑크푸르트선 및 상악 견치의 치축에 맞추어 기준 파노라마방사선사진을 촬영하였 다. 기준 파노라마방사선사진을 촬영 한 후, 두개골 고 정장치를 이용하여 상방, 하방, 좌측과 우측으로 $3^{\circ}, 5^{\circ}$, $7^{\circ}, 10^{\circ}, 12^{\circ}, 15^{\circ}, 20^{\circ}$ 회전시킨 상태에서 파노라마방사 선사진을 촬영하였다. 촬영된 영상은 DICOM (Digital imaging and Communication in Medicine)형식으로 저 장하고, INFINITT PACS software (Infinitt Co., Ltd., Seoul, Korea)를 이용하여 3백만 화소의 판독용 모니터 ME311L (Totoku Electric Co., Ltd., Tokyo, Japan)에서 금속구의 폭과 높이를 한 명의 관찰자가 일주일 간격으 로 3회 반복 측정하여 평균값을 구하였다.

확대율의 정의

수평 확대율 $=$ 파노라마 방사선사진에서 금속구의 폭 $\div$ 실제 금속구의 직경

수직 확대율 $=$ 파노라마 방사선사진에서 금속구의 높 이 $\div$ 실제 금속구의 직경

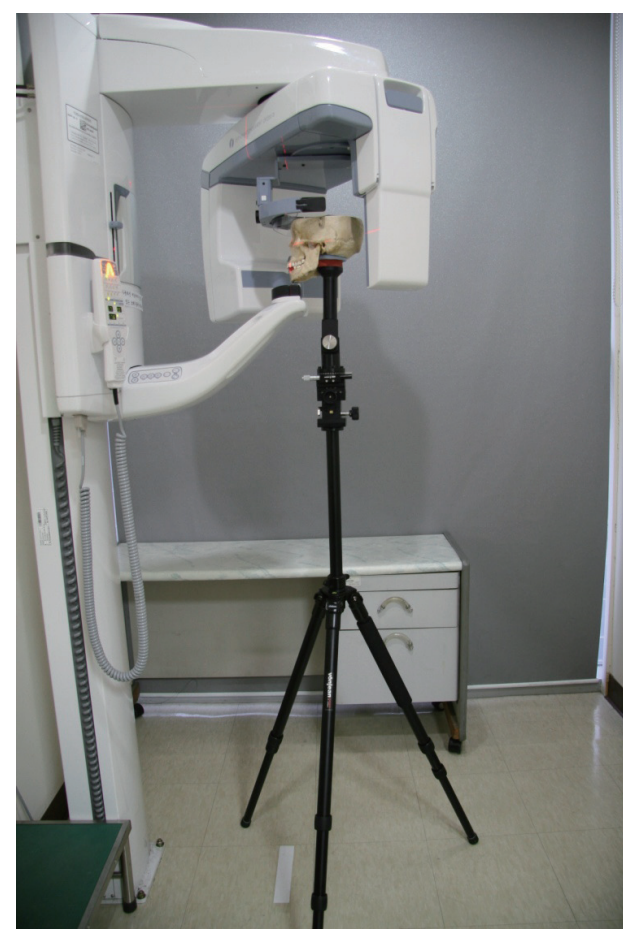

Fig. 2. Mounted dry skull in the dental panoramic X-ray machine. 


\section{통계분석}

데이터 분석은 PASW 19 (SPSS, Chicago, IL, USA) 을 이용하였고, independent samples t-test, one-way analysis of variance (ANONA)로 분석하였다. 분석결과 얻어진 유의확률 값이 0.05 이하 일 경우 통계적으로 유 의하다고 평가하였다. 유의한 차이가 있는 경우 Tukey, Duncan, and Scheffe test를 이용하여 사후 검정하였다.

\section{결과}

건조 두개골의 기준 위치 및 상방과 하방 회전에 따른 금속구의 수평, 수직 확대율은 Table 1, 2에 정리하였고, 좌측과 우측 회전에 따른 금속구의 수평 및 수직 확대율 은 Table 3, 4에 정리하였으며, 전체적인 수평, 수직 확 대율은 Fig. 3에 정리하였다. 각각의 조건에서 획득한 방 사선 사진은 Fig. 4,5 에 나타내었다. 기준 위치에서 촬 영된 파노라마방사선사진에서 금속구의 수평 확대율은 전치부(\#32, 42)에서 평균 $1.22 \pm 0.01$, 구치부(\#46, 47, 48)에서 평균 $1.44 \pm 0.01$ 로 통계적으로 유의한 차이를

Table 1. Horizontal magnification: upward and downward rotations

\begin{tabular}{cccc}
\hline Direction & $\begin{array}{c}\text { Degree of } \\
\text { Rotation }\left(^{\circ}\right)\end{array}$ & $\begin{array}{c}\text { Ant. } \\
(\text { mean } \pm \text { SD })\end{array}$ & $\begin{array}{c}\text { Post. } \\
\text { (mean } \pm \text { SD) }\end{array}$ \\
\hline Standard & 0 & $1.24 \pm 0.02$ & $1.40 \pm 0.03^{*}$ \\
position & 3 & $1.26 \pm 0.05$ & $1.43 \pm 0.38$ \\
Upward & 5 & $1.28 \pm 0.06$ & $1.45 \pm 0.03$ \\
& 7 & $1.29 \pm 0.05$ & $1.45 \pm 0.02$ \\
& 10 & $1.27 \pm 0.05$ & $1.44 \pm 0.03$ \\
& 12 & $1.25 \pm 0.04$ & $1.43 \pm 0.02$ \\
& 15 & $1.25 \pm 0.03$ & $1.41 \pm 0.03$ \\
& 20 & $1.26 \pm 0.04$ & $1.40 \pm 0.02$ \\
Downward & 3 & $1.07 \pm 0.02$ & $1.37 \pm 0.03$ \\
& 5 & $1.10 \pm 0.04$ & $1.39 \pm 0.03$ \\
& 7 & $1.14 \pm 0.03$ & $1.39 \pm 0.04$ \\
& 10 & $1.17 \pm 0.04$ & $1.41 \pm 0.06$ \\
& 12 & $1.17 \pm 0.05$ & $1.43 \pm 0.04$ \\
& 15 & $1.22 \pm 0.06$ & $1.44 \pm 0.04$ \\
& 20 & $1.32 \pm 0.02$ & $1.35 \pm 0.04$ \\
\hline
\end{tabular}

Ant., average magnification of the anterior metal ball (\#32, \#42); Post., average magnification of the posterior metal ball (\#46, \#47, \#48); SD, standard deviation.

* Statistically significant difference $(P<0.05)$ compared to Ant.
보였으나 $(P<0.05)$, 수직 확대율은 전치부에서 $1.29 \pm$ 0.00 , 구치부에서 $1.35 \pm 0.03$ 으로 유의한 차이는 보이 지 않았다 $(P>0.05)$.

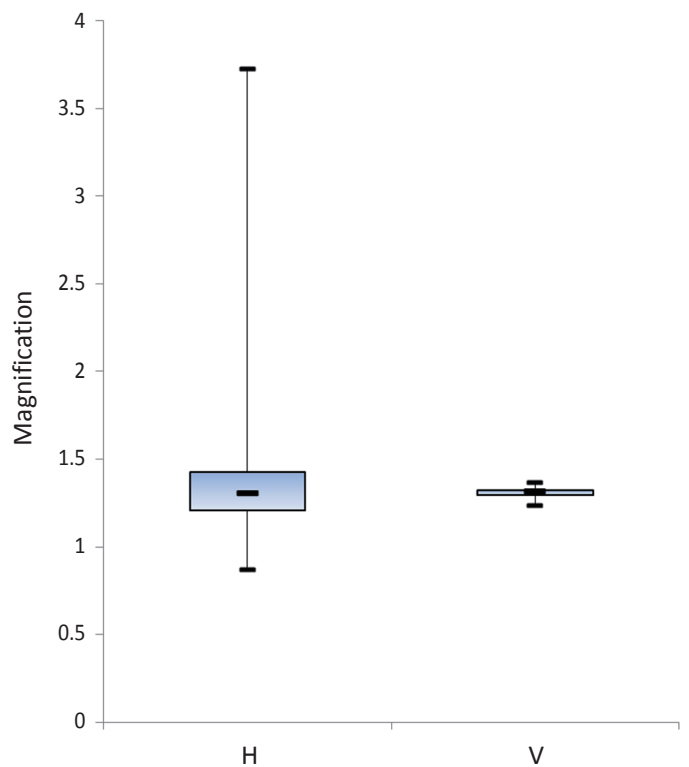

Fig. 3. Overall horizontal and vertical magnification. $\mathrm{H}$, horizontal; V, vertical.

Table 2. Vertical magnification: upward and downward rotations

\begin{tabular}{cccc}
\hline Direction & $\begin{array}{c}\text { Degree of } \\
\text { Rotation }\left(^{\circ}\right)\end{array}$ & $\begin{array}{c}\text { Ant. } \\
(\text { mean } \pm \text { SD) }\end{array}$ & $\begin{array}{c}\text { Post. } \\
\text { (mean } \pm \text { SD) }\end{array}$ \\
\hline $\begin{array}{c}\text { Standard } \\
\text { position }\end{array}$ & 0 & $1.31 \pm 0.03$ & $1.33 \pm 0.02$ \\
Upward & 3 & $1.30 \pm 0.03$ & $1.32 \pm 0.02$ \\
& 5 & $1.32 \pm 0.03$ & $1.33 \pm 0.01$ \\
& 7 & $1.31 \pm 0.03$ & $1.33 \pm 0.01$ \\
& 10 & $1.32 \pm 0.03$ & $1.32 \pm 0.01$ \\
& 12 & $1.31 \pm 0.02$ & $1.32 \pm 0.01$ \\
& 15 & $1.30 \pm 0.02$ & $1.32 \pm 0.01$ \\
& 20 & $1.32 \pm 0.03$ & $1.31 \pm 0.01$ \\
Downward & 3 & $1.27 \pm 0.04$ & $1.31 \pm 0.02$ \\
& 5 & $1.26 \pm 0.04$ & $1.31 \pm 0.02$ \\
& 7 & $1.28 \pm 0.04$ & $1.32 \pm 0.02$ \\
& 10 & $1.28 \pm 0.04$ & $1.32 \pm 0.02$ \\
& 12 & $1.28 \pm 0.03$ & $1.31 \pm 0.02$ \\
& 15 & $1.28 \pm 0.04$ & $1.33 \pm 0.03$ \\
& 20 & $1.29 \pm 0.03$ & $1.32 \pm 0.02$ \\
\hline
\end{tabular}

Ant., average magnification of the anterior metal ball (\#32, \#42); Post., average magnification of the posterior metal ball (\#46, \#47, \#48); SD, standard deviation. 
Table 3. Horizontal magnification: the left and the right rotations

\begin{tabular}{|c|c|c|c|c|c|c|}
\hline Direction & $\begin{array}{l}\text { Degree of } \\
\text { Rotation }\left(^{\circ}\right)\end{array}$ & $\begin{array}{c}\# 32 \\
(\text { Mean } \pm \text { SD })\end{array}$ & $\begin{array}{c}\# 42 \\
(\text { Mean } \pm \mathrm{SD})\end{array}$ & $\begin{array}{c}\# 46 \\
(\text { Mean } \pm \text { SD) }\end{array}$ & $\begin{array}{c}\# 47 \\
(\text { Mean } \pm \text { SD) }\end{array}$ & $\begin{array}{c}\# 48 \\
(\text { Mean } \pm \text { SD })\end{array}$ \\
\hline Standard position & 0 & $1.22 \pm 0.01$ & $1.26 \pm 0.00$ & $1.44 \pm 0.01$ & $1.40 \pm 0.00$ & $1.37 \pm 0.01$ \\
\hline \multirow[t]{6}{*}{ Left } & 3 & $1.14 \pm 0.03$ & $1.21 \pm 0.02$ & $1.52 \pm 0.03$ & $1.46 \pm 0.03$ & $1.39 \pm 0.02$ \\
\hline & 5 & $1.10 \pm 0.02$ & $1.21 \pm 0.03$ & $1.62 \pm 0.04$ & $1.52 \pm 0.00$ & $1.46 \pm 0.01$ \\
\hline & 7 & $1.04 \pm 0.03$ & $1.21 \pm 0.03$ & $1.77 \pm 0.05$ & $1.65 \pm 0.01$ & $1.53 \pm 0.02$ \\
\hline & 10 & $1.05 \pm 0.03$ & $1.21 \pm 0.01$ & $1.78 \pm 0.04$ & $1.64 \pm 0.03$ & $1.53 \pm 0.02$ \\
\hline & 12 & $0.95 \pm 0.04$ & $1.16 \pm 0.01$ & $2.49 \pm 0.08$ & $1.94 \pm 0.07$ & $1.71 \pm 0.03$ \\
\hline & 15 & $0.88 \pm 0.03$ & $1.05 \pm 0.03$ & $2.90 \pm 0.10$ & $3.73 \pm 0.16$ & $2.02 \pm 0.07$ \\
\hline \multirow[t]{7}{*}{ Right } & 3 & $1.23 \pm 0.01$ & $1.28 \pm 0.01$ & $1.37 \pm 0.01$ & $1.37 \pm 0.00$ & $1.36 \pm 0.01$ \\
\hline & 5 & $1.25 \pm 0.02$ & $1.24 \pm 0.00$ & $1.30 \pm 0.00$ & $1.31 \pm 0.01$ & $1.32 \pm 0.01$ \\
\hline & 7 & $1.26 \pm 0.01$ & $1.16 \pm 0.01$ & $1.25 \pm 0.00$ & $1.27 \pm 0.01$ & $1.29 \pm 0.01$ \\
\hline & 10 & $1.26 \pm 0.01$ & $1.07 \pm 0.01$ & $1.17 \pm 0.00$ & $1.21 \pm 0.01$ & $1.23 \pm 0.02$ \\
\hline & 12 & $1.22 \pm 0.01$ & $1.03 \pm 0.01$ & $1.13 \pm 0.01$ & $1.18 \pm 0.02$ & $1.21 \pm 0.01$ \\
\hline & 15 & $1.15 \pm 0.01$ & $0.99 \pm 0.01$ & $1.09 \pm 0.01$ & $1.12 \pm 0.01$ & $1.18 \pm 0.01$ \\
\hline & 20 & $1.02 \pm 0.01$ & $0.89 \pm 0.01$ & $1.01 \pm 0.00$ & $1.07 \pm 0.01$ & $1.11 \pm 0.01$ \\
\hline
\end{tabular}

$\mathrm{SD}$, standard deviation.

Table 4. Vertical magnification: the left and the right rotations

\begin{tabular}{|c|c|c|c|c|c|c|}
\hline Direction & $\begin{array}{c}\text { Degree of } \\
\text { Rotation }\left(^{\circ}\right)\end{array}$ & $\begin{array}{c}\# 32 \\
(\text { Mean } \pm \mathrm{SD})\end{array}$ & $\begin{array}{c}\# 42 \\
(\text { Mean } \pm \text { SD) }\end{array}$ & $\begin{array}{c}\# 46 \\
(\text { Mean } \pm \text { SD) }\end{array}$ & $\begin{array}{c}\# 47 \\
(\text { Mean } \pm \text { SD) }\end{array}$ & $\begin{array}{c}\# 48 \\
(\text { Mean } \pm \mathrm{SD})\end{array}$ \\
\hline Standard position & 0 & $1.29 \pm 0.00$ & $1.34 \pm 0.01$ & $1.35 \pm 0.03$ & $1.32 \pm 0.01$ & $1.32 \pm 0.01$ \\
\hline \multirow[t]{6}{*}{ Left } & 3 & $1.27 \pm 0.02$ & $1.31 \pm 0.03$ & $1.33 \pm 0.03$ & $1.32 \pm 0.03$ & $1.32 \pm 0.01$ \\
\hline & 5 & $1.27 \pm 0.02$ & $1.32 \pm 0.04$ & $1.33 \pm 0.03$ & $1.32 \pm 0.02$ & $1.32 \pm 0.03$ \\
\hline & 7 & $1.26 \pm 0.03$ & $1.33 \pm 0.02$ & $1.32 \pm 0.02$ & $1.34 \pm 0.02$ & $1.33 \pm 0.02$ \\
\hline & 10 & $1.26 \pm 0.01$ & $1.32 \pm 0.04$ & $1.33 \pm 0.01$ & $1.33 \pm 0.03$ & $1.33 \pm 0.02$ \\
\hline & 12 & $1.24 \pm 0.01$ & $1.28 \pm 0.02$ & $1.35 \pm 0.02$ & $1.35 \pm 0.01$ & $1.33 \pm 0.01$ \\
\hline & 15 & $1.25 \pm 0.03$ & $1.26 \pm 0.03$ & $1.36 \pm 0.01$ & $1.35 \pm 0.03$ & $1.37 \pm 0.02$ \\
\hline \multirow[t]{7}{*}{ Right } & 3 & $1.32 \pm 0.01$ & $1.33 \pm 0.01$ & $1.32 \pm 0.01$ & $1.32 \pm 0.00$ & $1.33 \pm 0.01$ \\
\hline & 5 & $1.35 \pm 0.01$ & $1.32 \pm 0.01$ & $1.32 \pm 0.01$ & $1.32 \pm 0.01$ & $1.32 \pm 0.01$ \\
\hline & 7 & $1.33 \pm 0.01$ & $1.29 \pm 0.01$ & $1.32 \pm 0.01$ & $1.31 \pm 0.02$ & $1.33 \pm 0.01$ \\
\hline & 10 & $1.33 \pm 0.01$ & $1.26 \pm 0.02$ & $1.31 \pm 0.01$ & $1.30 \pm 0.01$ & $1.32 \pm 0.01$ \\
\hline & 12 & $1.31 \pm 0.02$ & $1.27 \pm 0.01$ & $1.29 \pm 0.01$ & $1.31 \pm 0.01$ & $1.30 \pm 0.01$ \\
\hline & 15 & $1.31 \pm 0.01$ & $1.28 \pm 0.01$ & $1.29 \pm 0.01$ & $1.30 \pm 0.01$ & $1.30 \pm 0.00$ \\
\hline & 20 & $1.28 \pm 0.01$ & $1.25 \pm 0.02$ & $1.26 \pm 0.00$ & $1.28 \pm 0.01$ & $1.29 \pm 0.02$ \\
\hline
\end{tabular}

$\mathrm{SD}$, standard deviation.

기준 위치 대비 상방과 하방 회전에 따른 전치부 및 구치부의 수직 및 수평 확대율은 회전 각도에 따라 증가 하거나 감소하지 않고 기준 위치와 비슷한 값을 보였다 $(P>0.05)$.

건조 두개골의 좌측 회전 이동 시 금속구의 수평 확대 율은 좌, 우측 전치에 위치한 금속구의 경우 기준위치의 확대율에 비해 축소되어 나타났고, 그 중 좌측에 위치 한 \#32 금속구에서 $0.88 \pm 0.03$ 으로 가장 크게 나타났
다. 회전부위와 반대방향에 위치한 하악 우측 구치부의 금속구는 회전각이 증가할 수록 수평적 상의 확대가 크 게 나타났으며 이는 통계적으로 유의하였다 $(P<0.05)$ (Table 3). 우측 이동시 전치부 및 구치부에서 금속구의 수평확대율이 기준위치에 비해 감소하였다 $(P<0.05)$. 좌측과 우측 회전 이동에 따른 금속구의 수직 확대율은 통계적으로 유의하지 않았다 $(P>0.05)$. 

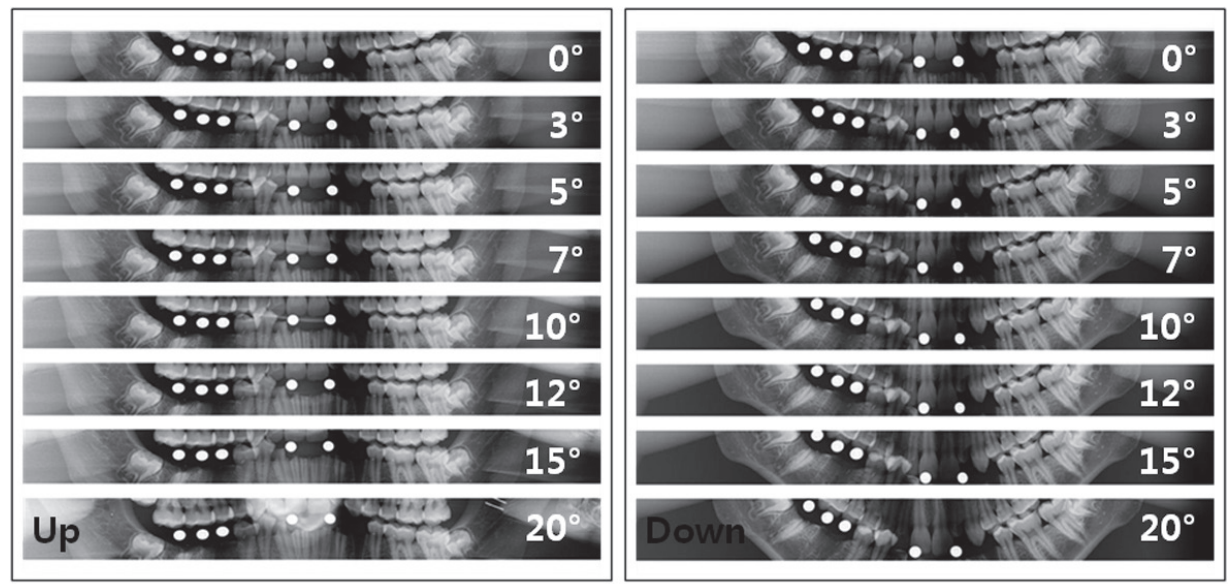

Fig. 4. Panoramic images according to upward and downward rotations.
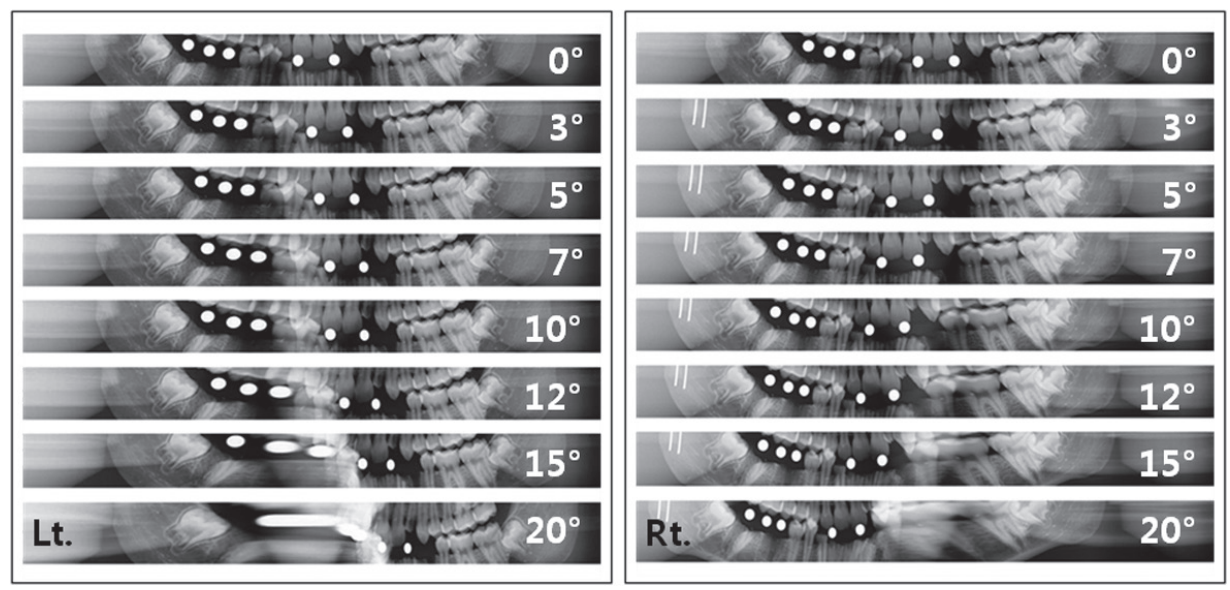

Fig. 5. Panoramic images according to the left and the right rotations.

\section{고찰}

이 연구의 목적은 기준위치에서 촬영된 파노라마방사 선사진과 상방, 하방, 좌측 및 우측으로 회전시켜 촬영 된 파노라마방사선사진의 수평 및 수직 확대율의 변화 를 비교, 관찰하는 것이었다. 파노라마방사선사진의 촬 영 시 피사체의 위치가 상층을 벗어나는 경우 상이 축 소되거나 확대되며 이를 토대로 골량을 계측하여 임플 란트를 식립하면 심각한 오류 및 합병증을 야기할 수 있 다. ${ }^{13-15}$ 대부분의 파노라마방사선사진 촬영기는 환자를 상층에 적절히 위치시키기 위해 지시광을 이용하게 되 는데, 실제 임상에서는 이러한 기준점 등을 참고하더라 도, 촬영기사의 숙련도, 환자의 협조도 등의 차이로 인
해 이상적인 파노라마방사선사진을 얻기가 힘들다. 또 한 파노라마방사선사진 촬영기의 X-선 관구와 디지털 센서 혹은 필름 수용기의 이동속도 및 회전중심의 개수 와 같은 여러 가지 설계 특성은 기종마다 다양하며, 같 은 기종의 모델에서도 사용에 따른 마모로 인해 상층의 위치가 변할 수 있다. ${ }^{16}$ 일반적으로 파노라마방사선사진 의 확대율은 환자의 촬영 시 위치 ${ }^{10}$ 악궁의 크기와 모양 에 영향을 받는다. 적절한 위치에서 촬영된 경우 사진의 수평확대율은 1.15 - 1.35, 수직확대율은 1.20 - 1.30으 로 보고 되었다. ${ }^{717}$ 같은 환자에서도 악궁의 만곡으로 인 해 개개의 치아 별로 확대율의 차이가 나며, 일반적으로 견치와 소구치 부위에서 최대이고, 제 3 대구치 부위에서 최소로 보고되었다. ${ }^{18}$ 
이번 연구에서는 수평 확대율이 1.22 - 1.44로 기존의 연구 ${ }^{7,17}$ 에 비해 다소 크게 나타났다. 이는 실험에 사용된 건조 두개골의 크기가 정상 성인의 건조 두개골보다 작 아서 금속구와 센서 사이의 거리가 증가한 것이 주요한 원인일 것으로 생각된다.

환자의 악궁을 상층에 제대로 위치시키지 못하면 수 직 및 수평 확대율의 변화가 나타나며 일반적으로 수직 확대율은 수평확대율에 비해 그 변화가 적다. ${ }^{9,13,19,20}$ 이 번 연구에서도 좌측과 우측 회전에서 회전각에 따라 금 속구의 수평 확대율은 최대 $3.73 \pm 0.16$ 으로, 수직 확대 율의 최대값인 $1.37 \pm 0.02$ 에 비해 높았다. 좌측 회전에 서 \#46 부위는 $5^{\circ}$ 의 회전만으로도 수평 확대율이 1.62 \pm 0.04 로 나타났다. 이는 실제 임상에서 환자의 머리가 약간만 변해도 임플란트의 식립에 큰 요소로 작용할 수 있음을 보여주었다.

이번 연구를 통해 파노라마방사선사진 촬영 시 환자 의 머리를 상층에 적절히 위치시키지 못하면 부위별로 다양한 상의 확대 및 축소가 야기되어 파노라마방사선 사진에서 계측된 골량이 실제 골 량과 비교해서 많은 오 차를 보일 수 있음을 확인하였다.

\section{결론}

파노라마방사선사진의 확대율은 촬영 시 환자의 머리 위치가 기준 위치에 비해 상방, 하방, 좌측 및 우측으로 회전될 때, 회전 각도와 악골 내의 해부학적 위치에 따 라 다양하며, 수평 확대율의 변화가 수직 확대율의 변화 보다 크다.

\section{Acknowledgements}

이 논문은 2012학년도 경북대학교 신임교수정착연구 비에 의하여 연구되었음.

\section{References}

1. Tal H, Moses O. A comparison of panoramic radiography with computed tomography in the planning of implant surgery. Dentomaxillofac Radiol 1991;20:40-2.

2. Xie Q, Soikkonen K, Wolf J, Mattila K, Gong M, Ainamo A. Effect of head positioning in pan- oramic radiography on vertical measurements: an in vitro study. Dentomaxillofac Radiol 1996;25:61-6.

3. Sakakura CE, Morais JA, Loffredo LC, Scaf G. A survey of radiographic prescription in dental implant assessment. Dentomaxillofac Radiol 2003;32: 397-400.

4. Bushong SC, Glaze SA, Foster JK, Copley RL, Miller JT. Panoramic dental radiography for mass screening? Health Phys 1973;25:489-94.

5. Keith DA. The detection of abnormalities in the jaws. A survey. Br Dent J 1973;134:129-35.

6. Choi BR, Choi DH, Huh KH, Yi WJ, Heo MS, Choi SC, Bae KH, Lee SS. Clinical image quality evaluation for panoramic radiography in Korean dental clinics. Imaging Sci Dent 2012;42:183-90.

7. Choi YG, Kim YK, Eckert SE, Shim CH. Crosssectional study of the factors that influence radiographic magnification of implant diameter and length. Int J Oral Maxillofac Implants 2004;19:5946.

8. Vazquez L, Saulacic N, Belser U, Bernard JP. Efficacy of panoramic radiographs in the preoperative planning of posterior mandibular implants: a prospective clinical study of 1527 consecutively treated patients. Clin Oral Implants Res 2008;19:81-5.

9. Tronje G, Eliasson S, Julin P, Welander U. Image distortion in rotational panoramic radiography. II. Vertical distances. Acta Radiol Diagn (Stockh) 1981;22:449-55.

10. Schiff T, D'Ambrosio J, Glass BJ, Langlais RP, McDavid WD. Common positioning and technical errors in panoramic radiography. J Am Dent Assoc 1986;113:422-6.

11. Stramotas S, Geenty JP, Petocz P, Darendeliler MA. Accuracy of linear and angular measurements on panoramic radiographs taken at various positions in vitro. Eur J Orthod 2002;24:43-52.

12. Dhillon M, Raju SM, Verma S, Tomar D, Mohan RS, Lakhanpal M, Krishnamoorthy B. Positioning errors and quality assessment in panoramic radiography. Imaging Sci Dent 2012;42:207-12.

13. Frederiksen NL. Diagnostic imaging in dental implantology. Oral Surg Oral Med Oral Pathol Oral Radiol Endod 1995;80:540-54.

14. Lee SS, Choi SC. Radiographic examination for 
successful dental implant. Korean J Oral Maxillofac Radiol 2005;35:63-8.

15. Kim YG, Lee YK, An SY. Effect of Head Positioning in Panoramic Radiography on the Vertical and Horizontal Magnification: Displacement along the Sagittal and Transverse Plane. J Dent Rehab App Sci 2013;29:249-58.

16. Devlin H, Yuan J. Object position and image magnification in dental panoramic radiography: a theoretical analysis. Dentomaxillofac Radiol 2013;42: 29951683. doi: 10.1259/dmfr/29951683.

17. Gomez-Roman G, Lukas D, Beniashvili R, Schulte W. Area-dependent enlargement ratios of panoram- ic tomography on orthograde patient positioning and its significance for implant dentistry. Int J Oral Maxillofac Implants 1999;14:248-57.

18. Samawi SS, Burke PH. Angular distortion in the orthopantomogram. Br J Orthod 1984;11:100-7.

19. Tronje G, Welander U, McDavid WD, Morris CR. Image distortion in rotational panoramic radiography. I. General considerations. Acta Radiol Diagn (Stockh) 1981;22:295-9.

20. Ji JH, Lee SR, Lee BD. Comparative study on alveolar bone height of pantomography and multiplanar reforamatted computed tomography. Korean J Oral Maxillofac Radiol 2004;34:159-64. 


\section{파노라마방사선사진에서 환자의 머리 위치가 하악 수직, 수평 확대율에 미치는 영향: 상하 및 좌우회전}

\section{김용건 ${ }^{1}$, 변진석 ${ }^{2}$, 안서영 ${ }^{3 *}$}

경북대학교 치의학전문대학원 ${ }^{1}$ 치주과학교실, ${ }^{2}$ 구강내과학교실, ${ }^{3}$ 구강악안면방사선학교실

목적: 이 연구는 파노라마방사선사진 촬영 시 환자의 머리 위치가 상방, 하방, 좌측 및 우측으로 회전됨에 따른 수평 및 수직 확대율의 변화를 비교 평가하는 것이었다.

연구 재료 및 방법: 직경 $4 \mathrm{~mm}$ 인 금속구 5 개를 건조 두개골의 하악 전치부(2개)와 우측 대구치부(3개)의 치조골 상방에 위치시켰다. 상하 및 좌우 회전량을 조절할 수 있는 두개골 고정장치에 건조 두개골을 고정시킨 후, 기준 위치와 회전 된 위치에서 파노라마방사선사진을 쵤영하였다.

결과: 기준 위치에서 평균 수평 확대율은 $1.22 \pm 0.01-1.44 \pm 0.01$ 이었고, 평균 수직 확대율은 $1.29 \pm 0.00-1.35 \pm$ 0.03 였다. 전치부와 구치부 비교시 수평 확대율은 전치부에서 $1.24 \pm 0.02-1.31 \pm 0.03$, 구치부에서 $1.40 \pm 0.03-1.33$ \pm 0.02 로 유의한 차이가 있었고 $(P<0.05)$, 수직 확대율은 차이가 없었다. 위치 변화에 따른 수평 확대율은 $0.88 \pm 0.03$ - $3.73 \pm 0.16$ 으로 기준 위치와 비교 시 통계적으로 유의한 차이를 보인 반면 $(P<0.05)$, 수직 확대율은 $1.24 \pm 0.01$ $1.37 \pm 0.02$ 로 차이가 없었다.

결론: 회전된 머리위치에서 파노라마방사선사진 촬영 시 수평 확대율의 변화가 크다.

(구강회복응용과학지 2014;30(1):1-8)

주요어: 머리위치; 확대율; 파노라마방사선사진

*교신저자: 안서영

(700-412) 대구광역시 중구 달구벌대로 2177번지 경북대학교 치의학전문대학원 구강악안면방사선학교실

Tel: 053-600-7423 | Fax: 053-425-6025 | E-mail: syan@knu.ac. kr

접수일: 2013년 12월 10일 | 수정일: 2014년 1월 30일 | 채택일: 2014년 3월 7일 